\title{
On the History of Modern Popular Music in Olomouc: Evolution of Folk, Country and Tramping Music before 1989
}

\author{
Jan Blüml
}

The history of Czech modern popular music before 1989 includes a number of diverse style and genre spheres. As concerns their social significance, the folk, country and tramping music sphere was undoubtedly one of the most important ones ${ }^{1}$. Among the three musical genres, tramping music has undergone the longest evolution in the national setting, as its origins date back to the 1920s; the following three decades are termed the traditional phase of the history of the music type. The modern era of Czech tramping music began in the 1960s, a period when the domestic popular music scene welcomed new style and genre types besides the dominant Anglo-American rock music: country and folk music. ${ }^{2}$ Although many of the momentous events associated with the constitution of the said musical spheres, i.e., folk, country and modern tramping music, took place in Prague, local, regional and district scenes started evolving in the sixties. Olomouc scene was no exception, and will be the subject matter of the following discussion. ${ }^{3}$

1 Although the three music genres in questions are not entirely compatible in the historic sense, they share many common features: at the music and musical structure levels, the social functions, organizational and institutional bases, etc. In this sense, folk, country and tramping music form a specific style and genre sphere, defined versus other spheres such as jazz or rock. In this sense, discussing these three areas of popular music together is entirely justified.

2 For general musical and historic characteristics of the said style and genre types, see for example Antonín Matzner, Ivan Poledňák and Igor Wasserberger, Encyklopedie jazzu a moderní populární hudby, 1. díl, část věcná [Encyclopedia of Jazz and Modern Popular Music, $1^{\text {st }}$ Volume, Subject Section] (Prague, 1983); Josef Kotek, Dějiny české populárni hudby a zpěvu, 2. dil, 1918-1968 [History of Czech Popular Music and Song] (Prague, 1998); Zdeněk R. Nešpor, Děkuji za bolest: náboženské prvky v české folkové hudbě 60.-80. let [Thank You for the Pain: Religious Aspects in Czech Folk Music in the 1960s, 70s and 80s] (Brno, 2006).

3 No paper directly dealing with the history of folk, country and tramping music in Olomouc has been published yet. Minor contributions to the understanding of the evolution of the scene before 1989 are contained in more aggregate works, such as Jiří Vondrák, Fedor Skotal, Legendy folku a country: jediný téměr úplný príběh folku, trampské a country písně u nás [Legends of Folk and Country: The 
Similarly to other towns and regions in Bohemia and Moravia, the evolution of the style and genre sphere in question in 1960s Olomouc was based in the rich musical life of the local tramping settlements. ${ }^{4}$ As concerns popularization of folk and country music in Olomouc, the increasing availability of records by prominent domestic and foreign musicians in the genre played an important role along with their live performances in the city. In this respect, the appearance of Pete Seeger, the legend of American folk and country music, in Fučík Hall on 24 March 1964, is certainly worth noting. It was one of the precious few concerts played by Seeger in Czechoslovakia at that time. ${ }^{5}$ The growing popularity of folk, country and modern tramping music in Olomouc region, which generally corresponded with the nation-wide trend, resulted in a systemic expansion of the local institutional base for this music in the following decades. ${ }^{6}$ Countless more or

Only and Nearly Exhaustive Story of Folk, Tramping and Country Song in Our Background] (Brno, 2004), and Miloslav J. Langer, Ivan Doležal, Porta znamená brána: ...i do nového století? [Porta Means a Gateway: ...also into the New Century?] (Prague, 2001), as well as the extensive television projects by Czech Television Bigbit [Big-Beat] (made in 1995-2000) and Legendy folku a country [Legends of Folk and Country] (made in 2001). Smaller-scale scholarly works include Helena Pavličíková's study The History of Czech Modern Folk Music in: Ivan Poledňák and Helena Pavličíková (eds.), Acta Universitatis Palackianae Olomucensis: Musicologica Olomucensia V (Olomouc, 2000), p. 113-122, and the summary of the sub-chapter Hudební kultura - Nonartificiální hudba [Musical Culture Nonartificial Music] by Filip Hajdu, Petr Lyko and Karel Steinmetz in their collective monograph Dějiny Olomouce, 2. dil [History of Olomouc, $2^{\text {nd }}$ Volume] (Olomouc, 2009), p. 428-429. Reflections on Olomouc music scene by way of portraits of its major exponents, particularly Karel Plíhal, can be found in Josef Prokeš’ book Estetická výstavba české folkové písně v 60.-80. letech XX. století [Aesthetic Conception of Czech Folk Song in the 1960s, 70s and 80s of the Twentieth Century] (Brno, 2003) and in Helena Pavličíková's diploma thesis Český folk - fenomén hudební i sociální [Czech Folk Musical and Social Phenomenon] (Olomouc, 1998). In addition to the aforementioned sources, the present study, aiming at presenting basic facts about the evolution of folk, country and modern tramping music in Olomouc in the 1960s to 1980s is largely based on period press, chiefly Olomouc periodicals Kdy, kde, co v Olomouci: kulturní zpravodaj [When, Where, What in Olomouc: Cultural Bulletin] and Stráž lidu: list Komunistické strany československé kraje olomouckého [Guard of the People: Bulletin of the Communist Party of Czechoslovakia of the Olomouc Region].

4 Jiři Vondrák, Fedor Skotal, Legendy folku a country: jediný téměr úplný príběh folku, trampské a country písně u nás (Brno, 2004), p. 43.

5 The visit of one of the founders of folk and country music Pete Seeger to this country in 1964 is generally considered to have been one of the most important motions stimulating the emergence of the Czech folk and country scene. See for example Helena Pavličíková Český folk - fenomén hudební i sociální (Olomouc, 1998), p. 20.

6 The mass popularity of the said music genres, especially folk, which culminated in the Czech context in the 1980s, is frequently associated, among other factors, with the communist cultural policy. In this period, the regime applied numerous repressive measures to systemically restrict the development of some music genres, especially rock music, whereby expanding the room for other style and genre types. An analysis of period press and other media then confirms the facts that the communists gave the style and genre sphere in question a preference over others to some extent in the 1980s; for example, the social and political criticism typical of folk music fitted well with the concept of the politically and socially committed singing promoted by the communists, which was 
less significant festivals and song contests were held in the 1970s and 80s, new clubs were set up. Local cultural organizations also regularly held popularization lecture series and seminars on key characters, bands and styles of the music genres in question.

The first mass popular music festival organized in Olomouc region was the Prvni Hanácký Folk \& Country Festival in 1973. However, the event, to be held in the amphitheatre in Náměšt na Hané on 10-12 August and attended by first-class Czechoslovak performers and over twenty thousand listeners, did not eventually take place for political reasons. ${ }^{7}$ For the most part, the festival was organized by performers from the Praguebased Šafrán musical association, headed by Olomouc-born singer-songwriter Jaroslav Hutka. The event, originally conceived as a festival of the young Czechoslovak musical scene, was officially sponsored by the North Moravian Services and Youth Enterprise. Concerning the dramaturgy, the festival concept was based on the Woodstock type of multi-genre events. ${ }^{8}$ Therefore, although the name, První Hanácký Folk \& Country Festival, defined a relatively narrow field of styles and genres, the performers invited came from many spheres of the domestic popular music, including jazz and rock. The posters advertised a rich programme. ${ }^{9}$ The performers would include folk singers Jaroslav Hutka, Vladimír Merta, Vlastimil Třešňák, Petr Lutka, Zuzana Michnová, Petr Kalandra, Dagmar Voňková, Miroslav Paleček and Michael Janík; the folk duo Hogel and Vychodil from Olomouc, the folk bands Minnesengři and Jiři Traxler's Český Skiffle, the country bands Taxmeni, Golden Strings (Zlaté struny), Falešní hráči, Luboš Andršt’s blues rock band Energit, Marian Varga's classical rock band Collegium musicum, Martin Kratochvíl's jazz rock band Jazz Q, and the art rock band Blue Effect (Modrý efekt). ${ }^{10}$

given room at official festivals such as Porta and Sokolov. See, for example, Czech Television series Bigbít. Part 20; Jiři Vondrák, Fedor Skotal, Legendy folku a country: jediný téměř úplný príběh folku, trampské a country pisně u nás (Brno, 2004), p. 434-448.

7 An administrative prohibition of a popular music event was nothing unusual in the so-called Normalization period. Until then, however, this type of repression mostly concerned rock music, which was more 'difficult' in the view of the communist state cultural policy. Although the festival had been banned, around five thousand music lovers converged in Olomouc and Prostějov on the day of its planned beginning. Security corps led them out of trains, interrogated and asked about the 'true' motive of the festival. See Tomáš Mazal, Písničkář o Jaroslavu Hutkovi [Singer-Songwriter: about Jaroslav Hutka] (Prague, 1981). Available online at <http://www.hutka.cz/new/html/pisnickar.html>.

8 The legendary multi-genre music festival at Woodstock, New York, in 1969, became a model for organizers of popular music events world-wide.

9 The posters, now deposited at Muzeum a archiv populární hudby (Popmuseum) in Prague, were made by Zorka Růžová, then wife of the singer-sonwriter Jaroslav Hutka.

10 Bands with English names were forced to change them as part of so-called Normalization. The paper quotes the original English names first; the Czech names under which the bands performed in the 1970s and 1980s follow in brackets. 
As for its programme concept and scope, the První Hanácký Folk \& Country Festival was a pioneering feat not only in the then North Moravian Region, but nation-wide. ${ }^{11}$ A symbolic remembrance of the music festival that never happened is Jaroslav Hutka's Náměšt' (Krásný je vzduch) [Náměšt - The Air is Fine], a song made by the singer-songwriter originally as the festival anthem and popularized in the following decades to become a 'classic' of the country's folk music repertoire. ${ }^{12}$

Porta was a festival inerasably associated with the history of Czech folk, country and tramping music, which also significantly contributed to the development of these style and genre types in Olomouc region in the latter half of the 1970s. The first year of the contest festival was held in Ústí nad Labem in 1967; the emergence of the new music festival focusing on country and western and tramping music was a natural response to the massive advent of new trends in modern popular music. In the course of the following twenty years, Porta grew into monumental proportions, rarely seen in the country's context. The social significance of the festival culminated in the latter half of the 1980s, when it was regularly visited by about thirty thousand listeners from all over Czechoslovakia and attracted extensive coverage by the country's mass media. ${ }^{13}$

The contribution of Porta to Czech popular music consisted by far not only in the public presentation of prominent performers of domestic folk, country and tramping music. As already suggested above, the scope and popularity of Porta defined the trend in these musical spheres to a significant degree. This was achieved due to the regular identification, awarding and media coverage of young talents. Karel Plíhal, a singer-songwriter from Olomouc, one of the most prominent members of the so-called second folk generation, started his career at Porta in the early 1980s. ${ }^{14}$ Other performers of the genres in question from Olomouc, highlighted by Ported, include the bands Falešní hráči, Dostavník, Bluegrass Nova, Hlavolam, and Damiján. ${ }^{15}$ In light of other facts, such as the amalgamation of local scenes, their systematic contacting and musical confrontation, establishing contacts abroad, popularization and promotion of the musical genres in question among listeners as well as professionals, establishment of organizational facilities for the

11 The organizers expected up to thirty thousand visitors; about twenty thousand tickets had been sold in advance. See Tomáš Mazal, Písničkář: o Jaroslavu Hutkovi (Prague, 1981). Available online at <http://www.hutka.cz/new/html/pisnickar.html >.

12 For more on the festival, see e.g. Czech Television series Bigbit. Part 20.

13 See the ePortýr website. Available online at <www.portyr.porta-festival.cz>; Jiří Vondrák, Fedor Skotal, Legendy folku a country: jediný téměr úplný př́běh folku, trampské a country písně u nás (Brno, 2004), p. 293-342; Helena Pavličíková, The History of Czech Modern Folk Music, in: Ivan Poledňák and Helena Pavličíková (eds.), Acta Universitatis Palackianae Olomucensis: Musicologica Olomucensia $V$ (Olomouc, 2000), p. 116; Czech Television series Legendy folku a country, parts 7, 8, 9.

14 See e.g. Czech Television series Bigbit. Part 42.

15 For example, the band Hlavolam, completely forgotten by now, entered the 'talking' history of Czech popular music with their song Ztráty a nálezy [Losses and Findings], included on the sound sampler of the national finals of Porta 1984 in Plzeñ, where the band received an honorary mention of the jury. Today, you can find the song at YouTube.com, for instance. 
genres, testing the capacities for open-air festivals in the country's context, etc., it can be concluded that the history of Czech folk, country and tramping music before 1989 was largely written by Porta. ${ }^{16}$

The Porta contest festival was not a one-off event, but consisted of a number of regional and, later on, provincial shortlisting concerts. ${ }^{17}$ Performers successful at the shortlisters would present themselves in the national finals of Porta in early July every year, the format of which was a classical popular music festival lasting several days. Olomouc organized the important event in 1977, 1978 and 1979. As in the other towns and regions of Bohemia and Moravia that hosted the national finals, Olomouc music scene too was given a massive impulse for developing. Among others, the benefits can be seen in popularizing the folk, country and tramping music genres among Olomouc, or more broadly, Moravian audiences, the expanding local listener for the music, and the initiation of dozens of new music groups. The 'contest' aspect characteristic of the festival was of some importance too; according to musicians themselves, the musical confrontation led to more intense practising and deeper self-reflection, thus forming the base for artistic growth. ${ }^{18}$

The organization of the national finals of Porta in the capital of Haná was initiated by Vladimír Ludmila, a member of the local band Dostavník, along with Přemyslav Nevrla, the then Secretary of the Olomouc District Committee of the Socialist Youth Association (the SSM). ${ }^{19}$ It was at a time when the councillors of Ústí nad Labem, to host the festival in that year, banned the event for political reasons at the last moment. 1977 Porta in Olomouc took place on in the traditional dates, from 7 to 10 July. The Moravian city hosted over 1,200 followers of folk, country and tramping music from all over Czechoslovakia to make an 'atmosphere unknown in Olomouc before'. ${ }^{20}$ The main festival programme took place in the Šibeník sports hall, lent to the organizers by Dukla

16 See Porta website at <www.porta-festival.cz〉; ePortýr website at <www.portyr.porta-festival.cz〉; Miloslav J. Langer, Ivan Doležal, Porta znamená brána: ...i do nového století? (Prague, 2001). However, it should be noted in this context that there were important musicians and associations of musicians who repudiated festivals such as Porta systemically. Their reasons included the connections of these music events to official communist institutions such as the Socialist Youth Association (SSM). These included predominantly singer-songwriters around the 1970s Prague Šafrán association. See Czech Television series Bigbit. Part 19; Přemysl Houda, Šafrán: kniha o sdružení písničkářù [Šafrán: a Book about the Association of Folk Singers] (Prague, 2008).

17 Regional and provincial rounds of Porta attended by Olomouc performers took place, among others, in Zábřeh na Moravě, Přerově, and Šternberku. They were organized by members of the local SSM offices. For Šternberk provincial rounds, these included Josef and Jarmila Nosek. See, e. g., "Šternberská Porta na výbornou: spojovala je hudba" [Successful Porta in Šternberk: They Were Connected by Music], Stráž lidu, 15 April 1983; “Oblastní kolo Porty ve Šternberku: svátek „mladé“ písničky” [Regional Stage of Porta in Šternberk: the Celebration of Young Song], Stráž lidu, 18 March 1984.

18 See e.g. "Intercountry”, Stráž lidu, 15 September 1986.

19 Miloslav J. Langer, Ivan Doležal, Porta znamená brána: ...i do nového století? (Prague, 2001), p. 72-73. The discussion of the Olomouc finals of Porta festival is largely based on the quoted book. 
Olomouc sports club. Accompanying music and cultural events were held in the Dvorák Hall and Geisler Brothers Hall, run by the local Culture and Recreation Park (PKO) branch, which co-organized Porta in that year with the Czech Central Committee and Regional Committee of SSM and printed the festival newsletter Portýr.

Musically speaking, the first Porta in Olomouc had a largely folk character. The chief award-winners, including the bands Brontosaurí, Slzy, and Pepa Kadeřábek's Pytlík from Prague, Variace from České Budějovice and V modrém stínu from Frýdštejn, made no room for local bands in that year. Dostavník thus became the most successful local band, winning the Mention of the Jury along with several groups from elsewhere. ${ }^{21}$ In light of the positive feedback on the festival among the city's councillors and public as well as the attending performers, deliberations on holding the following year's Porta in the same place began almost immediately after its end.

1978 Porta took place in Olomouc on 6-9 July. Although the organizers had made efforts to move the festival to the newly opened Slavie VŠ sports hall due to the increasing interest of listeners, the finals took place at Šibeník again, this time expanded with 300 additional seats, the capacity thus totalling around $1,500 .{ }^{22}$ In addition to the main concerts in the sports hall, which took place from half past seven to eleven o'clock in the evenings, shows took place in the Dům čs. armády cinema. The cinema also hosted the finals of the songwriters' contest, featuring the 15 best songs selected by a jury from 153 songs made by over sixty authors. The song Meditace [Meditation] by Ivo Viktorin and Karel Markytán, played by Flek from Zlín, won the Songwriter's Porta award. ${ }^{23}$ The programme Meet the Tramp Song, introducing both traditional and modern tramp songs played by tramping performers of every generation, was particularly popular with the audience that year. The sold-out Moravian Philharmonic Hall applauded in particular to the final unique performance by the 'tramping symphonic orchestra', composed of all the performers, featuring sixteen guitars, a mandolin, and four double basses, accompanied by a rich vocal choir of the performers and the audience. ${ }^{24}$ Like in 1977, no domestic band made it to the highest positions on the winner's rostrum that year. Falešní hráči won a side award in the form of Honorary Mention by the Jury. ${ }^{25}$

1979 Porta in Olomouc was a smooth follow-up on the two previous successful years. Again, the performances took place in the traditional venues: the Dukla sports hall at Šibeník, the open-air cinema and the Dvořák and Geisler Brothers Halls run by the PKO. ${ }^{26}$ The finals of the songwriters' contest as well as the new programme Tramping Calendar were shown in the Dům čs. armády cinema, which absolutely failed to accommodate the

${ }^{21}$ See festival history on the Porta website. Available online at 〈www.porta-festival.cz〉.

22 “Finále Porty 78" [Porta Final 78], Stráž lidu, 16 July 1978.

23 Miloslav J. Langer, Ivan Doležal, Porta znamená brána: ...i do nového století? (Prague, 2001), p. 75-78.

24 Ibid., p. 77.

25 See festival history on the Porta website. Available online at <www.porta-festival.cz〉.

26 "Porta opět v Olomouci" [Porta Again in Olomouc], Kdy, kde, co, June 1979; "Vítaný host: Porta 79" [Welcomed Guest: Porta 79], Stráž lidu, 5 July 1979. 
massive audience. ${ }^{27}$ Falešní hráči fared the best in the contest among the local bands, and won the top award: the Performer's Porta. ${ }^{28}$ Live coverage of the festival by Czechoslovak Radio was an important component of the third Porta in Olomouc and a milestone of the festival history. A live show introduced the organizers of Porta and several of the bands played. ${ }^{29}$ Although the general notion in 1979 was that Porta, one of the country's major popular music festivals, had definitively settled in Olomouc, the municipal authorities would not give consent to it in the following year. That was the end of the era of Portas in Olomouc, acclaimed by the period's critics in both artistic and organizations terms. ${ }^{30}$ However, the festival had undoubtedly helped highlight Olomouc on the Czechoslovak popular music map and contributed to the development of the local folk, country and tramping scene. ${ }^{31}$

Zlatý olomoucký tvarůžek contest festival was an important music festival in 1980s Olomouc, focused largely on folk, but also on country and tramping music and other genres. The cultural event, comprising music, literature and drama, regularly hosted the country's top performers in the genres in question, and soon won a firm position among the domestic popular music festivals. ${ }^{32}$ The popularity of Zlatý olomoucký tvarůžek was mainly thanks to the early interest of the media; Czechoslovak Radio and Czechoslovak Television Ostrava dedicated it regular room in its programme.

The festival of humour, as its initiators labelled it, was established in 1982. Besides the local PKO office, it was co-organized by the Municipal Committee of SSM and the Prague office of the Mladá fronta daily. The officially declared objective of the festival was to scout for young talented novelists, poets and playwrights and encourage them to produce humorist literature for SSM club activities. Another impetus for organizing the first year of Zlatý olomoucký tvarůžek was the one hundredth anniversary of the birth of author Jaroslav Hašek. ${ }^{33}$

The festival comprised two parts: a literary one and a club one. The literary contest was organized by the Mladá fronta office, which judged the literary pieces submitted and nominated participants for the Olomouc finals. The club art, guaranteed by the PKO and

27 The theatre would hold around 400 spectators. Dozens of listeners were crowded by the theatre windows and around the building. Miloslav J. Langer, Ivan Doležal, Porta znamená brána: ...i do nového století? (Prague, 2001), p. 80.

28 See festival history on the Porta website. Available online at <www.porta-festival.cz〉.

29 Miloslav J. Langer, Ivan Doležal, Porta znamená brána:...i do nového století? (Prague, 2001), p. 80.

30 "Porta pro nás úspěšná” [Porta Was Successful for Us], Stráž lidu, 10 July 1981.

31 See, e.g. "Intercountry”, Stráž lidu, 15 September 1986.

32 The festival frequently hosted famous persons of Czech popular culture. These included comedians Josef Dvořák, Jiři Wimmer, Jiří Lábus, Oldřich Kaiser, Jiř́i Císler, František Ringo Čech, Petr Novotný, Jiři Suchý, Jitka Molavcová, the musical duo Paleček and Janík, the singer-songwriter Pavel Dobeš, and others. See, e.g., Jiří Vondrák, Fedor Skotal, Legendy folku a country: jediný téměr úplný príběh folku, trampské a country písně u nás (Brno, 2004), p. 412-417; Czech Television series Legendy folku a country, part 9.

33 “Zlatý olomoucký tvarůžek” [The Golden Olomouc Curd], Kdy, kde, co, October 1984. 
Olomouc Municipal Committee in Olomouc, involved a broad range of drama, singing and musical genres. The contest accepted fragments of club programmes, cabarets, literary and music compositions, pantomime shows, sketches, small drama forms - monologues, dialogues, acted anecdotes - and songs with music accompaniment and authorial work of music bands. ${ }^{34}$ The finals of the club art contest and the ceremonial presentation of the winners of the literary contest took place in Olomouc in October. The venue of the Zlatý olomoucký tvarůžek contest festival was the Zenit cultural centre; part of the programme moved to S Club in the latter half of the 1980s.

Olomouc folk singer Karel Plíhal was the biggest star of the first years of the festival, as the humorist format of the festival suited him perfectly. In 1982, the only competitor to Karel Plíhal artistically was the Brno band Barel Rock, which also drew great attention. ${ }^{35}$ Karel Plíhal became the winner of the club component in the following year too. Ivo Jahelka and the Bratislava band LOJZO won the second place, the latter winning the greatest auditory response; Hop trop, a band from Prague, won the third place. In addition to the golden, silver and bronze tvarůžek, the jury also awarded honorary mentions as in Porta. Duo Potemník won one of them in that year. Other Olomouc performers, including the bands Hlavolam, Klubko, Piano, and Folk-lór, made more or less successful appearance in the following years of the festival. ${ }^{36}$

In addition to the above mentioned large-scale, nation-wide events, Olomouc hosted a number of smaller festivals and music displays, largely of local importance. Many of them focused primarily on folk music, the popularity of which culminated in the local context in the 1980s. ${ }^{37}$ For example, Moravian folk artists met regularly at local committed song festival. One of them, the Olomouc 83 Committed Song Festival was organised by the local SSM office and the Factory Club of the Revolutionary Union Movement (the ROH) in November 1983. Among others, the two-day event hosted two of the most prominent performers of the emerging folk generation: Karel Plíhal of Olomouc and Jaromír Nohavica of Český Těšín. ${ }^{38}$ The spring District Amateur Committed Arts Festival was another similar event, presenting the stars of Czech folk heaven besides beginning

34 "Zlatý olomoucký tvarůžek 82" [The Golden Olomouc Curd 82], Kdy, kde, co, January 1982; "Tvarůžek už podruhé” [The Golden Olomouc Curd for the Second Time], Stráž lidu, 10 October 1983.

35 "Zlatý olomoucký tvarůžek” [The Golden Olomouc Curd], Kdy, kde, co, December 1983.

36 See, e.g. "Čtvrtý ročník soutěže „amatérského“ humoru: Zlatý olomoucký tvarůžek” [The Fourth Year of the Amateur Humor Competition: the Golden Olomouc Curd], Stráž lidu, 22 October 1985; "Skončil šestý ročník soutěže mladého humoru: zrání Olomouckého tvarůžku" [The Sixth Year of the Amateur Humor Competition Is Over: Curing of the Golden Olomouc Curd], Stráž lidu, 28 October 1989.

37 In the 1980s, folk music was one of the socially most significant style and genre types of domestic popular music. In that period, the main folk music scene moved from Bohemia to Moravia, especially the cities of Ostrava, Brno and Zlin (then Gottwaldov), which were considered the central scenes for this type of music.

38 “Angažovaná písňová tvorba” [Engaged Song Output], Stráž lidu, 3 November 1983. 
performers. In 1984, they included Petr Lutka, a singer-songwriter from Prague, born in Hranice na Moravě.

The Vivat Viva festival, organized by the local PKO and SSM offices, was a specific musical rendezvous. From 1984 on, it regularly brought together physically handicapped folk and country artists from Olomouc and around. The festival became very popular in the 1980s, attested by the sold-out Ćajkovského cultural centre as well as the interest of Czechoslovak Radio, which made several live recordings from it. The Vivat Viva festival also presented well-established folk bands from Olomouc, including Folk-lór and Plejády. ${ }^{39}$

Music festivals focusing on folk, country and tramping music were also organized in Olomouc on the occasion of various anniversaries, feast days, etc. From 1984, local cultural newsletter advertised the several-day festival called Folkový Mixuláš. The event, held at S Club in early December each year, was initially composed as a combination of short film screenings and folk songs. However, the style purity was not observed by even the first year, which is attested by the presence of the band Relaxace from Prague, difficult to classify into a genre, as it built on Oriental inspirations, jazz, rock, Renaissance music and domestic folk songs. The increasing style and genre variety and presence of rock bands resulted in the name of the festival changing and dropping the adjective 'folkovy'. Regular musical rendezvous also took place during the Christmas period. These included the Folkové Vánoce, held by the ROH office at the M Club great hall, featuring new songs of Olomouc bands. In 1985, they included the bands M. O. P., Klubko, Plejády, and Folklór. Folk and country bands, such as Falešní hráči, were also fixed performers at annual Haná Harvest Home festivals, held at the turn of August. In the latter half of the 1980s, folk music followers in Olomouc also had the opportunity to visit events called Folkové léto. Performances by outstanding Czech folk musicians at the open-air cinema were organized by S Club. Similar events, called Folkový den, were organized by U Club on similar dates; the concerts took place in the Palackého University sports hall. A broad palette of musicians played for Olomouc public as part of performances at the summer stage in Smetana park every year starting from April. In addition to local bands, this was a frequent venue for nation-wide bands and musicians such as the Ulrychs' Javory and Bob Frídl.

The growing popularity of country music in Olomouc led in 1984 to the first Country Ball in local history. Its organizers were inspired by the repeated success of the country balls at Žofín in Prague..$^{40}$ The event, part of the celebrations on the twentieth anniversary of Olomouc PKO office, took place in the National House, accompanied by the bands Holátka, Ticho and Klubíčko, the well-know dance teacher Jasan Bonuš, and the presenter Petr Novotný. The massive interest of the public and the success of the first Country Ball in Olomouc compelled its organizers, PKO staff, to soon start organizing regular

39 "Zdařilá premiéra v Olomouci: At žije život” [A Successful Premiere in Olomouc: Hail Life], Stráž $l i d u, 20$ October 1984; "Na čtvrtém ročníku písničkového festivalu Vivat Viva: At žije život" [Visitation of the Fourth Year of the Song Festival Vivat Viva: Hail Life], Stráž lidu, 13 October 1987.

40 "1. country bál v Olomouci” [The First Country Ball in Olomouc], Kdy, kde, co, April 1984. 
country dance evenings. Beginning in the autumn of that year, popular music followers in Olomouc were thus given an opportunity to spend one evening a month dancing and listening to country music as part of the programme Dancing Country, taking place at the Čajkovského, and later on Zenit cultural centres. The events were accompanied by local country music bands, primarily Heřmánek and its guests. ${ }^{41}$

Besides festivals, regular club activities played an important role in the development of folk, country and tramping music in the North Moravian Region before 1989. Like in all of Czechoslovakia, many small clubs were established in the 1970s and 1980s; they hosted local musicians as well as bands and players from neighbouring towns and national celebrities. New clubs were set up in Ostrava, Třinec, Frýdek-Místek, Mohelnice, and Jeseník, for example. Olomouc was no exception from the trend. ${ }^{42}$

The local Dex Club (Divadlo experimentu) offer opportunities to meet folk from the latter half of the 1960s. For some time, the institution, founded by the artistic trio Pavel Dostál, Jaroslav Göbel and Richard Pogoda in 1966, became the home scene to Karel Kryl, one of the best-known domestic folk singers to be. The young performers songs were played along with songs by local musicians, such as Pavel Dostál, Richard Pogoda, already mentioned, as well as Miroslav Nop and Jan Vičar, in programmes called Písničkál [Song Programme] and Text-fórum [Text-Forum] ${ }^{43}$ In 1967 and 1968, Karel Kryl performed for Olomouc audiences in his first solo recitals, Konfrontace s Dylanem [Confrontation with Dylan] and KK recitál, aneb království za koně [KK Recital, the Kingdom for a Horse]. In the following years, the playing of folk, country and tramping music in Olomouc was also associated with the Tramp Club, an institution set up by the local SSM office. The music was also played at the Palackého University dormitories, where regular 'Folk Thursdays' were held from the 1970 s. $^{44}$

U Club and S Club became prominent Olomouc clubs before 1989. The students' U Club was founded in 1984 with the support of Palackého University management. The University General Committee of SSM became its official sponsor. The dramaturgy of the club aimed to encompass the broadest possible spectrum of the young people's interests. It included performances by both amateur and professional small-scale drama troupes, various types of audiovisual programmes, lectures, listening and dancing discotheques, and above all, popular music concerts. ${ }^{45}$ In light of the nation-wide flowering of the folk genre in the 1980s, this type of music occupied a significant portion of the U Club pro-

41 "Tančíme country" [We Are Dancing Country], Kdy, kde, co, December 1984.

42 See, e.g. Jiři Vondrák, Fedor Skotal, Legendy folku a country: jediný téměr úplný př́běh folku, trampské a country písnè u nás (Brno, 2004), p. 391-448.

43 Daniela Bakerová et al., Karel Kryl s námi 1944-1999 [Karel Kryl with Us 1944-1999] (Prague, 1999), p. 16-18; Vojtěch Klimt, Akorát, že mi zabili tátu: př́běh Karla Kryla [They Just Killed My Father: the Story of Karel Kryl] (Prague, 2010), p. 62-65. Helena Pavličíková, Český folk - fenomén hudební i sociální (Olomouc, 1998), p. 24

45 "U-klub: něco o nás" [U Club: Something about Us], Kdy, kde, co, July 1989; "U Club”, Kdy, kde co, July 1990. 
gramme. The decade saw such well-known folk performers as Pavel Žalman Lohonka, Paleček and Janík, Jan Burian, and the band Bakaláři, as well as local bands M. O. P. and Piano, for instance. Dozens of first-rate performers in the styles and genres in question appeared for Olomouc audiences in S Club above all, which in the 1980s held prominent nation-wide events such as Zlatý olomoucký tvarůžek and national festivals of SSM club activities. ${ }^{46}$ The performers who played here in the 1980s included Jaromír Nohavica, Marsyas, Nerez, Vladimír Mišík, Dagmar Voňková, Hradištan, Kapitán Kid, Vladimír Merta, Pavel Dobeš, Petr Lutka, Wabi Daněk, Poutníci, Minnesengři, and many more. Locals included Karel Plíhal and Bluegrass Nova, of course.

Olomouc Music Theatre operated under the District Cultural Centre also played an important role in popularizing folk, country and tramping music with Olomouc audiences. ${ }^{47}$ From the latter half of the 1960 s onward, the institution organized regular concerts, musical events with playbacks, and lectures on prominent singers and bands in the genres concerned. Live music performances throughout the years included local bands and performers such as Golden Strings (Zlaté struny), Dostavník, Hogel and Vychodil, Falešní hráči, Plejády, H. L. T., Plíharmonyje, Karel Plíhal, and Na Ex. Guest artists included Rangers (Plavci), CK Vocal, Nerez, Bratři Ebenové, Jaroslav Hutka, and Jan Burian and Jiří Dědeček.

As mentioned above, live music was complemented with listening programmes with playback music and screenings on personalities such as Jim Reeves, Johnny Cash, Bob Dylan, Joan Baez, Simon and Garfunkel, Ray Charles, Joni Mitchell, and Neil Young. Jiří Grossmann's programme Golden Records in Country and Western - a selection of the greatest hits of American provenance - was re-run many times. Regular authors of the said programmes included Jiří Frišauf and Vít Hrubý. Jiří Černý also presented similarly arranged programmes in Olomouc. Seminars on the history of the style and genres types in question were presented by Miloslav Langer, country music expert and author from Prague, in his Country and Western Wave.

Part of the programmes in Olomouc Music Theatre was arranged as reports from prominent music festivals. Miroslav Nop, for instance, introduced popular music followers in Olomouc to the final concerts at Porta and other musical events. The programmes included screenings of video recording from festivals abroad, such as the famous folk festival in Newport. Specific seminars on the emergence, history and play technique of the banjo, combined with singing American folk songs, were presented repeatedly in Olomouc by Jan Bican, member of the bluegrass band Zřídlo from České Budějovice.

The already repeatedly mentioned Culture and Recreation Park (PKO) was a key institution that affected the cultural life in Olomouc to a great extent. The local office

46 In 1985, for example, Olomouc S Club was rated as the best professional youth club in North Moravian Region. See "Pestrá paleta pořadů pro všechny: Primát pro olomoucký S-klub" [Colorful Palette of Programmes for All: the Victory for Olomouc S Club], Stráž lidu, 15 May 1986.

47 Olomouc Music Theatre was established in 1968 as a branch of Prague Music Theatre. Its founder and the first director was Rudolf Pogoda. 
of the central state organization was established in 1964 after the existing institutional network of municipal public education establishment was restructured. From the mid 1960s onward, the PKO organized a number of significant festivals, concerts and music events, in addition to its numerous other activities. They included performances of well-established stars of Czechoslovak popular music, such as Greenhorns (Zelenáči), Rangers (Plavci), Nad’a Urbánková and Jiř́i Brabec's Country Beat, Waldemar Matuška and KTO, Michal Tučný, Ivan Mládek, Spirituál Kvintet, etc. Among other properties, the PKO administrated the Zenith cultural centre, Cajkovského cultural centre, and the open-air cinema, where the said artists performed.

As in other towns of Bohemia and Moravia, Olomouc region too saw a relatively large community of followers and performers of the popular genres of folk, country and modern tramping song in the 1970s and 80 s. In the course of the said period, a number of bands and solo performers appeared, some of whom even succeeded outside the district, or region's boundaries and made a pronounced contribution to the nation-wide popular music scene.

Bands that introduced country and western music to Olomouc audiences at the turn of the 1960s included Golden Strings (Zlaté struny) and Golden River Boys. Their programmes such as Country Matinee were to be seen at the Geisler Brothers and Dvorák Halls. Severní hvězdy were the top of local country and tramping music scene in the first half of the 1970s. The band, based in the rich musical culture of the local tramping settlements, introduced itself to a broader listening public at the national Folk and Country Festival in Jablonec in $1972 .{ }^{48}$ They won the country music category at the North Moravian regional round of Porta in Karviná in the same year. A year later, the band was recognized at the same festival for its instrumental proficiency: their play on the banjo and mandolin in particular. Severní hvězdy frequently performed at the local Tramping Club music hall; they also presented their song programmes, such as the successful 1974 Konkurs [Audition], elsewhere, included the Geisler Brothers Hall under the auspices of the PKO, and in other venues. ${ }^{49}$

Speaking of the band Severní hvězdy, one must mention Bluegrass Nova, one of the most prominent country and bluegrass performers not only on the local scene, but in the whole Moravian context. Bluegrass Nova was established by ex-Severní hvězdy musicians Petr Schäfer, Aleš Kubis and Cyril Žádník in 1973. At their heyday at the turn of the 1970s, the band was composed by bandmaster Petr Schäfer, the mandolin player Pavel Šandera, the singer and bass player Aleš Kubis, the singer and guitar player Vladimír Bican, the violin player Vladimír Sýkora, the singer and mouth organ player Pavel Dokoupil, the banjo player Milan Žourek, and the singer Cyril Žádník. The bandmaster Petr Schäfer explained the band's general interest in bluegrass by a link to Moravian folklore: 'We find common denominators with our cimbalom music, we found the different

\footnotetext{
48 Jiři Vondrák, Fedor Skotal, Legendy folku a country: jediný téměr úplný príběh folku, trampské a country písnè u nás (Brno, 2004), p. 43.

49 "Severní hvězdy opět na scéně” [Severní Hvězdy Again on the Scene], Stráž lidu, 8 December 1973.
} 
instrumentation with an approximately identical function very attractive. ${ }^{50}$ As suggested by the band's name, the ambition of its members was to overcome the existing boundaries of the style and shift them towards new musical possibilities. In that sense, the band's later inclination to rock music aspects somehow anticipated the new bluegrass style of the 1980s known as newgrass. ${ }^{51}$

Bluegrass Nova had a relatively broad and varied repertoire. In the early stages of its existence, the band did mostly adaption of Scottish and Irish folklore, which generally is an important starting point for American bluegrass. At 1979 Porta in Olomouc, the band surprised the listeners with an adaption of George Gershwin's Summertime. In the same year, the Porta jury gave Bluegrass Nova an award for instrumental proficiency, the play on the mouth organ in particular. The same happened at Porta in Sokolov the following year. A fundamental milestone for the band came with the fifteenth anniversary of Porta in Plzeñ in 1981, when they won the main award for creative work as well as an award for instrumental proficiency for the guitar player Vladimír Bican's performance. The band won more proficiency awards at the national festival finals in 1983 and 1984. The numerous successes and increasing renown of Bluegrass Nova at the turn of the 1970s led the band to co-operate with Czechoslovak Radio, for which the band recorded several of its songs. The band also appeared in Ostrava TV programme Čtyři, šest, dvanáct. ${ }^{52}$ In the mid 1980s, Bluegrass Nova was one of the precious few Czechoslovak popular bands that had an opportunity to present their arts in Western Europe. This was at the bluegrass festival in Toulouse, France, in 1984, where it was sent by representatives of the Institute for Cultural and Educational Activity of the Ministry of Culture in Prague, the Young Creativity Club, the Central Committee of SSM, and the Prague Porta headquarters, to represent Czechoslovak country music. The band was officially nominated for its longstanding high artistic quality. ${ }^{53}$

Besides participating at top local folk, country and tramping music events, such as Porta and Mohelnický dostavník, Bluegrass Nova regularly performed at smaller contest festivals and clubs. After 1985, it made regular performances in S Club in Olomouc with a programme called Studio BGN. It was a composed evening comprising several parts. The first was a presentation of novelties in international bluegrass music, then there

S0 Alena Divínová, “Úspěšný zájezd do Francie: hudba nezná hranic” [Successful Tour in France: the Music Without Boundaries], Stráž lidu, 15 June 1984.

51 Miloslav J. Langer, Ivan Doležal, Porta znamená brána: ...i do nového století? (Prague, 2001), p. 81.

52 Josef Nosek, "Bluegrass Nova desetiletá" [Bluegrass Nova is Ten Years Old], Stráž lidu, 3 October 1983.

53 The one-hour-long recital was accepted by the international audience of the Toulouse festival very warmly. Bluegrass Nova was one of the few bands then that the audience made to play several encores. Festival contestants from the United States also showed interests in the band's recordings. After the three-day festival, aired on the local radio among others, Bluegrass Nova set out for a weeklong French tour along with the local band Amazing Grass. Both the bands then performed together in Valašské Meziříčí, Olomouc S Club, and the Porta festival. See Alena Divínová, "Úspěšný zájezd do Francie: hudba nezná hranic”, Stráž lidu, 15 June 1984. 
was a concert of Bluegrass Nova and guest bands, including Kopr, Heřmánek, Modřina, and Terč. Bluegrass Nova popularizing club programmes with music tastings of records included a profile of the famous American banjo player Earl Scruggs.

Falešní hráči, founded by Palackého University students in the autumn of 1971, were one of the most prominent country music bands in Olomouc in the 1970s. Given the fact that the members of the band, performing under the PU Science Faculty, were mostly undergraduates, who would often leave Olomouc after graduation, the line-up of the band constantly fluctuated. In 1974, when Falešní hráči were an important component of the popular music scene in Olomouc, the line-up comprised the guitar player and singer Pavel Vodička, the mandolin player, singer, music and lyrics author Miroslav Novotný, the banjo player and lyricist Miroslav Nop, the violin player Radim Čermák, the bass player Pavel Kuchař, the singer Zdena Hustá, the percussionist and singer Jan Novotný, and the presenter Václav Frank. ${ }^{54}$

The band, which in the first phase of its existence focused on classic country and western as well as adaption of domestic and foreign folk songs, struck first major success in 1973. The band won the Pony Express contest in Prríbor and the regional Porta in Karviná. At the national finals of 1973 Porta in Jablonec nad Nisou, Falešní hráči represented the North Moravian Region and won an honorary mention for a pure-style rendering of the Czech folk song Hop hej, cibulárí In that period, the band also recorded several songs for Czechoslovak Radio and, later on, co-operated with Ostrava and Bratislava television studios. The year 1975 was a milestone in the band's musical evolution. Falešní hráči then focused exclusively on their own songs, authored by the collective of Miroslav Nop, Richard Pogoda and Karel Plíhal. ${ }^{55}$ The distinct swing inspiration that penetrated the band's repertoire is later to be heard to a great extent in Karel Plíhal's solo works.

The band maintained its high professional quality throughout the 1970s. In 1978, Falešní hráči won the honorary mention of the jury at the national finals of Porta; and won the main award - the Performer's Porta. Winning the regional round of Political Song Festival in Opava in the same year cemented their presence at the national Political Song Festival in Sokolov. ${ }^{56}$ Olomouc audiences had numerous opportunities to meet Falešní hráči. They included regular club performances; they appeared in drama performances by Oldřich Stibor Theatre such as Touha pod jilmy [Desire under the Elms], Večer tríkrálový [Twelfth-Night] and Divotvorný klobouk [Magical Hat] and at political and social/cultural events such as the traditional Haná festivals in Náměšt na Hané.

Dostavník was the competing band for Falešní hráči in 1970s country music. The band, headed by P. Voltner, won numerous awards in regional Portas throughout its

54 “Olomoučtí Falešní hráči” [Falešní Hráči from Olomouc], Stráǎ lidu, 14 May 1974.

55 “Rozdávají radost” [They Are Giving a Pleasure], Stráž lidu, 17 August 1979.

56 The Political Song Festival in Sokolov was established in 1973. One of the impetuses for it was the successful Porta finals in Sokolov in 1972. For more on the Political Song Festival in Sokolov and its relation to Porta, see e.g. Jiři Vondrák, Fedor Skotal, Legendy folku a country: jediný téměr úplný príběh folku, trampské a country písnè u nás (Brno, 2004), p. 434-448. 
existence. For example, at 1974 Porta in Ostrava, Dostavník won the second place and honorary mention for a socially committed song; they won the Mention of the Jury at 1977 Porta. As with Falešní hráči, Olomouc audiences met Dostavník regularly as part of club programmes. The members of the band, especially the bass player Vladimír Ludmila, also have a great merit for arranging the Porta finals in the capital of Haná in 1977, 1978, and 1979. ${ }^{57}$

The duo Hogel and Vychodil became relatively well-known in 1970s folk music in Olomouc. The co-operation of the singer, guitar and mouth organ player Pavel Hogel and the vocalist, keyboard and guitar player Ota Vychodil started in the first half of the 1970s. The duo performed not only on the club scene of the then North Moravian Region, but also in Prague. There, they maintained close co-operation with the Šafrán folk music association, containing singer-songwriters such as Jaroslav Hutka, Vladimír Merta and Vlastimil Třešñák.

A new folk band, Plejády, appeared in Olomouc in 1975. The band, formed by local SSM organization members, progressively worked from its first performances in local youth clubs and secondary schools and colleges to top-ranking national music events. In May 1978, the band presented itself at the fifth year of the regional protest song contest O černou rúži 78, attended by the winning bands of the regional Political Song Festival in Opava, the regional 1978 Porta, and the regional Committed Work Festival in Ostrava. Eventually, Plejády won the contest in Karviná. Moreover, they won the Jury Awards for vocal work. ${ }^{58}$ The band also struck great success at the 1979 national Political Song Festival in Sokolov, where Plejády were the first band from Olomouc District to arrive, having won the regional Political Song Festival. At the Sokolov festival, Plejády were among the most employed amateur bands: the band performed at three out of the eight concerts. The high acclaim of Plejády by the festival jury was also attested by the fact that one of their songs - Ćarostroj [A Magical Machine] - was included in the Sokolov anthology Písně našich dnů [The Songs of Our Days]. ${ }^{59}$ In addition to the Sokolov festival, where the band reappeared the following year, Plejády also attended the national Porta finals and the international folk music festival in Dresden. The band also made guest appearances at festivals in South Moravian and East Slovakian Regions. Listeners could also meet them at events such as youth meetings with exponents of the political and public life at Poustevny. Besides contest festival success, Plejády won numerous awards by district and regional authorities for their socially and politically committed songs; the band won the Regional Brontosaurus Award, the Bronze Medal for Socialist Upbringing, the Award for Cultural Growth in North Moravian Region, and many more. In its successful period at the turn of the 1970s, the band performed with the guitar player and singer L. Dobeš,

\footnotetext{
57 See Miloslav J. Langer, Ivan Doležal, Porta znamená brána: ...i do nového století? (Prague, 2001).

58 “Plejády nejlepši”" [Plejády Are the Best], Stráž lidu, 16 May 1978.

59 “Sokolov 79” [Sokolov 79], Stráž lidu, 17 April 1979.
} 
the singer H. Kunčarová, the pianist M. Maruška, the flute player J. Dobešová, and the bass guitar player V. Křepský. ${ }^{60}$

For over a decade of their existence, Plejády won a number of followers in all age groups. Their composed events such as Slavné postavy historie a pohádkové ríše [Great Characters in History and the Fairytale Kingdom], Hvězdy a hvězdičky [Stars and Starlets], Od Darwina k Dänikenovi [From Darwin to Däniken], and Báječná rada [Marvellous Word of Advice], were seen by hundreds of spectators from not only Olomouc and around, but all of Moravia, in the 1970s and 80s. The said programmes, largely authored by the bandmaster Ladislav Dobeš, combined modern folk music built on precise vocals and smart instrumentation with a wide range of non-musical performances: theatre gags and humorous speeches. ${ }^{61}$ Some of Dobeš's successful songs were also recorded by Czechoslovak Radio Ostrava and Brno studios.

The modern tramping band Tuláci became popular among the broader Olomouc public in the latter half of the 1970s. The band was quite popular particularly in Olomouc countryside, where it performed frequently in co-operation with local Public Education Clubs and cultural centres. Their successful concerts included performances in Těšetice and Lutín. However, even the urban listeners could hear Tuláci, not only in Olomouc, but also Valašské Meziříčí and Ostrava, for example. The band's concert calendar often included special concerts for children and youth. One of these events was an entertaining morning contest with music and theatre, organized by the band regularly once a month in Hejčín Children's Home. Tuláci also performed at summer children's camps. ${ }^{62}$

The 1980s in folk music are associated with the advent of a new generation of performers. Karel Plíhal, Olomouc-born singer-songwriter is one of the most prominent members of this so-called second generation of Czech folk music. The singer and guitar player, today one of the 'classics' of the genre, began his music career in the 1970s. His first band was called Hučka, whose repertoire built on the music of Greenhorns, the founders of Czech country music. ${ }^{63}$ It was superseded by country-swing Falešní hráči, with whom Plíhal won the 1979 Porta. At the turn of the seventies, he and two of his fellows from the latter band, the guitar player Luboš Schneider and bass player Vojslav Ketman, founded Plíharmonyje, which won Porta in 1981 and $1982 .{ }^{64}$ In 1983, Plíhal already a solo performer - won the first award in the performer contest of Porta for his song Akordy [Chords]. The said achievements in the early 1980s made Karel Plíhal one of the most closely watched persons in Czechoslovak folk music. In the following years, the singer-songwriter became an esteemed guest at many festivals, music shows and clubs all over the Czech Republic. Plíhal's noticeable musical and literary gift, far exceeding

\footnotetext{
60 “Úspěšné Plejády” [Successful Plejády], Stráž lidu, 8 February 1985.

${ }^{61}$ See "Olomoucké Plejády slavily úspěch” [Plejády from Olomouc Were Celebrating a Success], Stráž lidu, 11 October 1976; "Plejády u vojáků” [Plejády Visited Soldiers], Stráž lidu, 16 November 1976.

62 “Tuláci hrají pro radost” [Tuláci Are Playing for Fun], Stráž lidu, 25 June 1975.

63 See Karel Plíhal's website. Available online at <www.karelplihal.cz>.

64 “Úspěšná hudební skupina” [Successful Music Band], Stráž lidu, 15 March 1982.
} 
the borders of Olomouc scene, was first captured on a Supraphon long-play record (no name) in 1985.His albums released in the following years also achieved massive popularity among folk music followers. For example, the 1988 record Karel Plíhal... Emil Pospísil... [Karel Plíhal... Emil Pospíšil...] was the result of Plíhal's co-operation with rock and folk singer and guitar player Emil Pospíšil from Olomouc.

Karel Plíhal's songs have always been acclaimed by domestic musical critics. Their lyrics are usually recognized for their original poetics, playfulness, wit, onomatopoeia, rich vocabulary and wide variety of original rhymes, metaphors and topics. His musical accompaniment captivates with its complex and imaginative guitar play, not entirely typical in folk music, showing many jazz and swing inspirations. Not only as a singersongwriter, but also as the author of drama scores for the Moravian Theatre and music director and arranger, Plíhal has made a great contribution to the evolution of music culture in Olomouc. ${ }^{65}$

From 1981, the local folk music scene also welcomed H. L.T. The band, frequently hosting Karel Plíhal in the early 1980s, comprised M. Veselovský, P. Veselovský, M. Obenaus, and Z. Krňávková. Folk-lór was another reinforcement to the local folk music scene in the same period. The band, formed in 1982 by a merger of Nenudi se and bluegrass Almara, focused on Bohemian, Moravian and American folk songs. Their speciality was own adaptations of Haná folk songs. The band members took materials for their adaptations chiefly from Jan Poláček's and František Sušil's song anthologies. Its artistic concept made Folk-lór one of the few Czech bands of the 1980s that focused on stylized folk music, along with Minnesengři from České Budějovice and Kantoři from Hradec Králové. The latter band shared Folk-lór's liking for using instruments not quite typical for folk music, such as jingle bells, Jew's harp, cowbells, etc.

The band won many an award throughout its existence. In 1985, 1986 and 1987, Folk-lór won regional Portas. In 1988, they won the Performer's Porta, the main festival award. In their most successful period - the latter half of the eighties - Folk-lór line-up was the bandmaster, singer and flute player Soňa Vidličková, the guitar and mandolin player Milan Vidlička, the guitar player and singer Pavel Mazal, the violin player and singer Blanka Tkadlčíková, the guitar player and singer Jaroslava Hasalíková, and the double bass player Arnošt Šuba. ${ }^{66}$

Folk music follower in Olomouc as well as music-loving audiences in other Moravian regions and Bohemia had relatively frequent opportunities to meet Folk-lór. They included the following festivals and contests: Folkové léto in Telč, Folkové prázdniny in Náměšt nad Oslavou, Folkové přástky in Litomyšl, Moravské folkové léto in Lipník nad Bečvou, Chvaletický širák, Horácký džbánek, Zpívající totem in Karviná, and Mohelnický dostavník. As with other Olomouc bands, Folk-lór also recorded several of its songs for Czechoslovak Radio. Moreover, the band was allowed to perform in Czechoslovak

${ }^{65}$ Helena Pavličíková, Český folk - fenomén hudební i sociální (Olomouc, 1998), p. 110-113; Josef Prokeš, Estetická výstavba české folkové písně v 60.-80. letech XX. století (Brno, 2003).

${ }_{66}$ Marie Hovadíková, "S Folk-lórem o Portě” [With Folk-lór about Porta], Stráž lidu, 16 August 1988. 
Television programmes Zpívánky and Televizní klub mladých (TKM). Folk-lór performances in Olomouc frequently hosted the bands Kopr and Amfora, playing related styles.

Reviewers and observers of Olomouc music scene regarded the local folk band Piano as interesting music of high technical quality in the latter half of the 1980s. The band was formed in December 1983. The original duo gradually grew to a quartet of not quite typical instrumentation: the bass player Petr Čechák, the piano and bassoon player Richard Mlynář, the percussionist Milan Raška, and the guitar player Jan Švec. In 1987, the band succeeding in presenting itself at the provincial round of Porta in Sternberk and then the regional round in Sumperk. The response the concerts elicited won the band the ascent to authors' Porta in 1987, and an offer to perform in Ostrava Television programme Aréna and participation in Mikrofórum Praha live radio programme. In the same period, Piano received an honorary mention at Akademická Praha festival. The band also reaped success in the following year, having won the provincial Porta and the regional round of Elementary Artistic Activity. At the national finals of 1988 Porta, the band Piano was among the companies most acclaimed by the audience: the band won the Spectators' Award and the Original Humour Award. Piano's successful tracks included the song Mysli $\left[\right.$ Thinks]. ${ }^{67}$

Olomouc folk music in the mid 1980s was also reinforced by the folk-swing band M. O. P. (Malá olomoucká písnička), which declared its style as 'balcony house folk'. Although the company achieved no remarkable success at larger festivals such as Porta, they gradually built quite a listener base in their home territory. M. O.P.'s repertoire comprised simple songs reflecting on the difficulties of 'ordinary' life, authored by the bandmaster, guitar and flute player and singer Karel Löffler. The band's music was characterised by a rich sound with a noticeable presence of string instruments. The substance of the lyrics, dealing in a humorous form with issues such as alcoholism, bribery, promiscuity, disillusionment, marriage problems, etc., was largely supported by the suggestive and coarse singing of Karel Löffler and Jana Pešková. The band's dozens of original songs included Kámoška samoška [A Friend Samoška], Šedá [Grey], Růžence [Beads], and Libye [Libye]. ${ }^{68}$

Other Olomouc folk music bands in the 1980s included Hlavolam, for example. The company entered history of Czech popular music especially when it attended the national Porta finals in Plzeñ in 1984, where they received an honorary mention of the jury. Their song called Ztráty a nálezy became part of the festival sound sampler, whereby it was preserved for future listeners. ${ }^{69}$ In the latter half of the 1980s, the band Damiján drew attention on the Olomouc as well as national festival scenes. The band, introducing successfully Leona Machálková, a prominent face of Czech pop music and the musical scene, was the discovery of the provincial Porta in 1987. The band members were recognized

\footnotetext{
67 Daniela Nováková, "Piano”, Kdy, kde, co, October 1989.

68 "Tip na podvečer: Folk pro starší a pokročilé” [Evening Tip: Folk for Older and Advanced Ones], Stráž lidu, 17 September 1987.

69 The song Ztráty a nálezy is currently available at YouTube.com, for instance.
} 
for sensitively combining music, lyrics and performance in their song Nedélní odpoledne na sesterské ubytovně [Sunday Afternoon in the Sister's Hostel]. In the following year, Damiján won the main award in the national Porta finals in Plzeň.

Heřmánek was a country band that won a great popularity on Olomouc scene in the 1980s. The band, founded in Dolany in the autumn of 1983, achieved that largely thanks to regularly appearing in the programme Country Dancing. However, these events in the Zenit cultural centre were primarily dedicated to dancing lessons, organized by the local country dancing club Kroky. Besides Heřmánek, other bands accompanied the course, eagerly attended by Olomouc public for several years: Kopr, Brzdaři, Country motor, Bluegrass Nova, Bumerang, and Olešnica.

A more important appearance of Heřmánek was in the regular Thursday club programme known as Country Bazar, which involved many interesting guests as well. These included the band Poutníci from Brno, the banjo player and member of Zrídlo Jan Bican from České Budějovice, the local Bluegrass Nova, and Country Style from Police nad Metuji. Among other things, the musical programme was accompanied by short cartoon films, reports from various folk and country festivals, such as the Banjo Jamboree and Porta, talking about music, etc. Jiří Pospíšil, the bandmaster, banjo player and song arranger for Heřmánek, was the successful presenter of the composed event. In addition to him, the band in the latter half of the 1980s comprised the bass player Radek Pospišil, the singer and violin player Jaroslav Janšta, the singer, guitar and mouth organ player Ladislav Brix, and the percussionist Milan Grund.

Heřmánek was never an ambitious concert band that would collected awards from festivals such as Porta. The band members regarded their frequent appearances at dancing balls as positive. Besides the above mentioned programme Dancing Country, Olomouc audiences could meet the band at regular country balls and other similar events. In addition to their own songs, the band's repertoire drew mostly on 'classics' of country and bluegrass, such as Osborn Brothers, The Dillards, and Irish folk music. ${ }^{70}$

Modern tramping music was represented on Olomouc music scene in the 1980s by Klubko, for example. Although the band was officially established only in 1982, its history dated back to the sixties, when Miloš Krejzlík, future bandmaster of Klubko, and Václav Hřiva began co-operating on songs. Both the songwriters produced an extensive repertoire over the years, which became the basis for Klubko songs in the 1980s. Already in 1970, however, the duo Krejzlík-Hřiva published their own song anthology as part of the Tramping Songs series. Besides Miloš Krejzlík, the ambitious band was composed of three other experienced musicians: the ex-member of Pardubice tramping band Vodáci Jindřich Jung played the guitar, mandolin and mouth organ, the ex-member of successful Olomouc band Dostavník Miroslav Hampl played the double bass, and Brno musician Aleš Horák played the twelve-string guitar. ${ }^{71}$ After its establishment, Klubko played in

70 “Dolanský Heřmánek” [Heřmánek from Dolany], Kdy, kde, co, August 1988.

71 Helena Čermáková, "Spojuje je společný zájem o trampskou píseň: Olomoucké Klubko” [They Are Connected by a Common Interest in Tramping Music], Stráž lidu, 6 August 1985. 
many clubs all around the country and regularly attended Porta festivals. It was also a regular guest at festivals and music displays such as Svojšický slunovrat, Smiřický hrnec, and Mohelnický dostavník.

As already mentioned in the introduction, the origins of folk, country and modern tramping music in the chosen context date back to the 1960s. The situation was similar for other newly emergent genres in Czech modern popular music, such as rock music, and the institutional facilities for the style and genre sphere in question also began forming noticeably in the latter half of the decade. An example may be the emergence of the Porta festival in 1967, which largely dictated the history of folk, country and modern tramping music in the two following decades and is undoubtedly one of the country's most important popular music festivals in retrospective. Although many of the notable events associated with the constitution of Czech folk, country and modern tramping music took place in Prague, local, district and regional scenes also started evolving successfully in the sixties. Olomouc was no exception in this sense, with many interesting musicians and bands appearing in the 1970s and 80s. Examples may include the top-ranking domestic bluegrass band, Bluegrass Nova, and the star of the Czech folk heaven, singer-songwriter Karel Plíhal. Olomouc deserves an honorary mention in the history of folk, country and modern tramping music not only thanks to these and other musicians and bands, but also the fact that it organized the successful Portas in 1977, 1978, and 1979.

\section{Zur Geschichte der modernen Populärmusik in Olmütz:} die Entwicklung der Countrymusik, Folkmusik und Wanderlieder vor dem Jahr 1989

\section{Zusammenfassung}

Die Geschichte der modernen tschechischen Populärmusik vor dem Jahr 1989 umfasst eine Vielzahl von vermischten Stilrichtungen. Aus der Sicht der gemeinschaftlichen Bedeutung gehören zu den wichtigsten von ihnen zweifellos die Bereiche der Folkmusik, Countrymusik und Wanderlieder. Obwohl viele bedeutende Ereignisse, die mit den Konstitutionen dieses Musikbereiches verbunden sind, sich in Prag abspielten, entwickelten sich seit den Sechzigerjahren erfolgreich insbesondere lokale Kreis- und Bezirksszenen. Nicht einmal die Olmützer Szene war eine Ausnahme, in der während der Sechziger und Achtziger Jahre eine Menge von bemerkenswerten Solisten und Gruppen erschienen. Ein Olmützer Künstler, der einen gesamtstaatlichen Erfolg erzielte, war Karel Plíhal. Der Volksmusikliedermacher begann seine Karriere in den Sechziger Jahren in der örtlichen Gruppen Hučka, Falešní Hráči und Plíharmonyje. Zu Anfang der Achtziger Jahre begab er sich auf Solokarriere. Dank seiner hohen originellen Werke reihte sich Plíhal zu den bedeutendsten Darstellern, der sogenannten zweiten Generation der tschechischen Folkmusik, ein. Eine Olmützer Countrygruppe, die deutlich in das gesamtstaatliche Geschehen eingriff, war beispielsweise Bluegrass Nova. 
Parallel zur steigenden Beliebtheit der Folkmusik, Countrymusik und Wanderlieder bei dem Olmützer Publikum kam es zu einer Ausbreitung der örtlichen institutionalen Basis dieser Musik. Während der Sechziger und Achtziger Jahre in Olmütz fanden zahlreiche mehr oder weniger bedeutende Festivals und Musikschauen statt, und es entstanden neue Clubs. Die lokalen Kulturorganisationen veranstalteten ebenfalls regelmäßige Populärvortragszyklen und Seminare über die Schlüsselfiguren, Gruppen und Stile des inkriminovierten Musikbereiches. Ein Ehrenplatz in der Geschichte der heimatlichen Populärmusik in Olmütz gebührt auch dank der Veranstaltung einem der bedeutendsten heimatlichen Festivale - Porta, das hier sehr erfolgreich in den Jahren 1977, 1978 und 1979 stattfand.

\section{K historii moderní populární hudby v Olomouci: vývoj country, folku a trampské písně před rokem 1989}

Resumé

Historie české moderní populární hudby před rokem 1989 zahrnuje množství rozmanitých stylově žánrových okruhů. Z hlediska společenského významu k těm nejdůležitějším bezpochyby patřil okruh folku, country a trampské písně. Ačkoliv se mnoho významných událostí spojených s konstitucí těchto hudebních oblastí odehrávalo v Praze, od šedesátých let se úspěšně rozvíjely rovněž lokální krajské a okresní scény. Výjimkou nebyla ani olomoucká scéna, kde se během sedmdesátých a osmdesátých let objevilo množství pozoruhodných sólistů a skupin. Olomouckým umělcem, jenž dosáhl celorepublikového úspěchu, byl Karel Plíhal. Folkový písničkář zahájil svoji kariéru v sedmdesátých letech v místních skupinách Hučka, Falešní hráči a Plíharmonyje. Na počátku osmdesátých let se vydal na sólovou dráhu. Díky své vysoce originální tvorbě se Plíhal zařadil k nejvýznamnějším představitelům tzv. druhé generace českého folku. Olomouckou country skupinou, která výrazněji zasáhla do celorepublikového hudebního dění, byla například Bluegrass Nova.

Paralelně s rostoucí oblibou folku, country a trampské písně u olomouckého publika docházelo k rozšiřování místní institucionální základny této hudby. Během sedmdesátých a osmdesátých let v Olomouci proběhlo nespočet více či méně významných festivalů a hudebních přehlídek, vznikaly nové kluby. Místní kulturní organizace rovněž pravidelně pořádaly popularizační přednáškové cykly a semináře o klíčových postavách, skupinách a stylech inkriminovaných hudebních oblastí. Čestné místo v historii domácí populární hudby Olomouci náleží také díky pořadatelství jednoho z nejvýznamnějších domácích festivalů - Porty, která zde velmi úspěšně proběhla v letech 1977, 1978 a 1979. 


\section{Keywords}

Olomouc; popular music; folk music; country music; tramping music; Porta; Karel Plíhal; Bluegrass Nova.

\section{Klíčová slova}

Olomouc; populární hudba; folk; country; trampská hudba; Porta; Karel Plíhal; Bluegrass Nova. 